\title{
ISOLADO DO VÍRUS DO MOSAICO DO PEPINO OBTIDO DE BANANEIRA NO ESTADO DE SÃO PAULO PERTENCE AO SUBGRUPO IA
}

\author{
MARCELO EIRAS ${ }^{1, *}$, ADDOLORATA COLARICCIO $^{1, *}$ \& ALEXANDRE L.R. CHAVES ${ }^{1}$ \\ 'Centro de Sanidade Vegetal, Instituto Biológico de São Paulo, Cx. Postal 12898, CEP 04010-970, São Paulo, SP; \\ e-mail: eiras@biologico.br
}

(Aceito para publicação em 05/12/2000)

Autor para correspondência: Marcelo Eiras

EIRAS, M., COLARICCIO, A. \& CHAVES, A.L.R. Isolado do vírus do mosaico do pepino obtido de bananeira no Estado de São Paulo pertence ao subgrupo Ia. Fitopatologia Brasileira 26:53-59. 2001.

\section{RESUMO}

Em 1996, foi feita a caracterização parcial de um isolado do vírus do mosaico do pepino (Cucumis mosaic virus, CMV) obtido de bananeira (Musa sp.) proveniente do município de Miracatu, SP. Com o objetivo de se determinar o subgrupo do isolado de CMV, recorreu-se às técnicas de ELISA, RT-PCR, RFLP e seqüenciamento de fragmentos de RNA genômico. Amostras de folhas infetadas, desidratadas com cloreto de cálcio e armazenadas à $-20^{\circ} \mathrm{C}$ desde 1994 na viroteca do Laboratório de Fitovirologia e Fisiopatologia, foram inoculadas em plantas de Nicotiana glutinosa. Dez dias após a inoculação, folhas apresentando mosaico foram utilizadas para DAS-ELISA e extração de RNAs totais. Em ELISA, houve reação apenas contra o anti-soro específico para CMV subgrupo I. Através de RT-PCR com primers desenhados para anelar em regiões conservadas da porção terminal 3' do gene da capa protéica, foi amplificado um fragmento de DNA com 486 pares de bases. O produto obtido via RT-PCR foi submetido à digestão com as enzimas $E c o$ RI, HindIII, BamHI e MspI, obtendo-se um padrão de restrição esperado para o subgrupo I. Estes resultados foram confirmados através do seqüenciamento do produto de PCR, o qual apresentou homologia de $96 \%$ a $98 \%$ com os isolados do CMV pertencentes ao subgrupo I. Pelos sintomas observados na hospedeira diferencial Vigna unguiculata, o isolado foi confirmado como sendo do subgrupo Ia.

Palavras-chave: Cucumovirus, biologia molecular.

\section{ABSTRACT \\ Isolate of Cucumber mosaic virus obtained from banana in São Paulo State, Brazil, belongs to the subgroup Ia}

In 1996, an isolate of Cucumber mosaic virus (CMV) obtained from banana in São Paulo State, was partially characterizated. In order to establish its CMV subgroup, ELISA, RT-PCR, RFLP, and sequencing of a fragment of genomic RNA were used. Infected leaf samples that have been stored since 1994 on calcium chloride at $-20{ }^{\circ} \mathrm{C}$ were inoculated in Nicotiana glutinosa plants. Ten days after inoculation, the leaves showing mosaic symptoms were used for ELISA and total RNA extraction. The ELISA results were positive for the antiserum against CMV subgroup I.
By RT-PCR, with primers designed to anneal the conserved regions of the coat protein gene3' end, a 486 base pair DNA fragment was amplified. The RFLP results with EcoRI, HindIII, BamHI and MspI enzymes showed a typical digestion pattern for subgroup I. These results were confirmed by sequencing the PCR product showing a homology of 96 to $98 \%$ with the subgroup I CMV isolates. Based on symptom expression on the differential host Vigna unguiculata, the isolate was confirmed as belonging to the subgroup Ia.

\section{INTRODUÇÃO}

A clorose infecciosa, como é conhecida a doença causada pelo vírus do mosaico do pepino (Cucumber mosaic virus - CMV) família Bromoviridae gênero Cucumovirus em bananeira (Musa sp.), foi descrita pela primeira vez por Magee (1930) na Austrália. Posteriormente, a doença, também

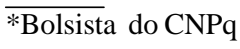

chamada de mosaico e "heart rot" da bananeira, foi observada em outros importantes países produtores de banana como Filipinas, Índia, Porto Rico, Colombia e Estados Unidos (Palukaitis et al., 1992).

No Brasil, a ocorrência do CMV em bananeira foi relatada, nos Estados de São Paulo (Colariccio et al., 1996), Rio de Janeiro (Ribeiro et al., 1975), Minas Gerais (MacielZambolim et al., 1994), Pernambuco (Medeiros, 1963), Ceará (Lima \& Gonçalves, 1988) e mais recentemente no Pará 
(Trindade et al., 1998).

O CMV apresenta genoma, de senso positivo, dividido em três segmentos de RNA (1, 2 e 3) além de um RNA subgenômico (4) (Palukaitis et al., 1992).

Com base no relacionamento sorológico (Hsu et al., 2000), gama de hospedeiras e padrão de dsRNA (Daniels \& Campbell, 1992), mapeamento de peptídeos da capa protéica e técnicas de hibridização (Edwards \& Gonsalves, 1983), Reverse Transcriptase - Polymerase Chain Reaction (RTPCR) (Rizos et al., 1992) e seqüenciamento (Hu et al., 1995), o CMV atualmente está dividido em dois subgrupos denominados subgrupo I, com as estirpes Fny, M, C, D, O, Y e subgrupo II, com as estirpes WL, Q, entre outras (Wylie et al., 1993). Daniels \& Campbell (1992), ainda sugerem a divisão do subgrupo I em "a" e "b" de acordo com a sensibilidade à temperatura, sintomas em plantas indicadoras e o padrão de dsRNA.

A RT-PCR vem sendo empregada para a detecção de diversos vírus de plantas (Eiras et al., 1998). Para o CMV, vários trabalhos têm sido publicados envolvendo esta técnica, tanto para a detecção universal das espécies do gênero Cucumovirus (Choi et al., 1999), como para a detecção específica do CMV (Wylie et al., 1993; Hu et al., 1995). Também têm sido observados os padrões de restrição através de RT-PCR seguido de Restriction Fragment Lenght Polymorphism (RFLP), de diversos isolados de CMV (Rizos et al., 1992), inclusive de bananeira (Boari et al., 2000; Espinha, 1999; Singh et al., 1995).

Estudos de DAS-ELISA, RT-PCR, RFLP e seqüenciamento de fragmento do gene da capa protéica foram realizados com um isolado proveniente do município de Miracatu, SP, (Colariccio et al., 1996) visando determinar o subgrupo ao qual pertence o isolado de bananeira.

\section{MATERIAL E MÉTODOS}

\section{Origem do isolado}

O isolado de CMV estudado é proveniente do Vale do Ribeira, município de Miracatu, Estado de São Paulo. Amostras de folhas de Nicotiana glutinosa L. infetadas, provenientes da viroteca do Laboratório de Fitovirologia e Fisiopatologia do Instituto Biológico de São Paulo, desidratadas em cloreto de cálcio a $-20^{\circ} \mathrm{C}$, desde 1994 , foram utilizadas como fonte para inoculação mecânica.

\section{Inoculação Mecânica}

As folhas de $N$. glutinosa desidratadas infetadas pelo CMV foram utilizadas para inoculação mecânica em plantas de N. glutinosa e Vigna unguiculata (L.) Walp. segundo procedimentos usados por Colariccio et al. (1996). Dez dias após a inoculação, amostras de folhas de $N$. glutinosa com sintomas sistêmicos de mosaico foram coletadas para os testes de ELISA e extração de RNAs totais.

\section{DAS-ELISA}

Utilizou-se o teste de DAS-ELISA com anti-soros policlonais comerciais específicos para os subgrupos I e II. O procedimento foi realizado conforme Converse \& Martin (1990) com algumas alterações recomendadas pelo fabricante (Agdia 1000 reagent). As leituras de absorbância (405 nm) foram feitas 45 min após a aplicação do substrato (pnitrofenilfosfato), sendo os resultados analisados pela relação da média das leituras (triplicata) das amostras infetadas, sobre a média das leituras das amostras sadias (I/S). As leituras foram feitas no aparelho Microplate reader 3550-UV (BioRad).

\section{Extração de RNAs totais}

Para a extração de RNAs totais, $1 \mathrm{~g}$ de amostras foliares de $N$. glutinosa, apresentando sintomas de mosaico e deformação, foram submetidas ao procedimento descrito por Chomczynski \& Sacchi (1987). Amostras de RNAs totais de folhas de $N$. glutinosa sadias também foram extraídas para servirem como controle negativo.

\section{RT-PCR}

Para a RT-PCR, partiu-se de $5 \mu \mathrm{l}(1 \mu \mathrm{g})$ de RNAs totais extraídos e utilizou-se o protocolo descrito por Wylie et al. (1993). Utilizaram-se os primers denominados CMV 1 (5' GCCGTAAGCTGGATGGACAA 3'), desenhado para anelar na região não traduzida do terminal 3' do RNA 3, do nucleotídeo 2019 ao 2038 (senso complementar), e CMV 2 (5' TATGATAAGAAGCTTGTTTCGCG 3'), desenhado para anelar no gene que codifica para a proteína da capa, do nucleotídeo 1551 ao 1573 (senso viral) (Figura 1). O tamanho do fragmento de DNA esperado é de cerca de 488 pares de bases (pb) para os isolados de CMV do subgrupo I, e de cerca de 500 pb para os isolados do subgrupo II. Para a PCR, foi utilizado o termociclador Programmable Thermal Controller - PTC100 (MJ Research), e os reagentes utilizados foram do kit para PCR Taq DNA Polymerase, recombinant (Gibco BRL). As condições para a PCR constaram de uma desnaturação inicial a $92{ }^{\circ} \mathrm{C}$ por $3 \mathrm{~min}$, seguida de 35 ciclos a $95^{\circ} \mathrm{C}$ por $1 \mathrm{~min}, 60^{\circ} \mathrm{C}$ por $1 \mathrm{~min}$ e $72^{\circ} \mathrm{C}$ por $1,5 \mathrm{~min}$, com uma extensão final de 7 min a $72^{\circ} \mathrm{C}$. Os fragmentos de DNA amplificados foram visualizados em gel de agarose 1,2\% corado com brometo de etídeo sob luz ultra-violeta.

\section{RFLP}

Os produtos de RT-PCR amplificados foram submetidos à digestão com as enzimas Eco RI, HindIII, BamHI e MspI (Gibco BRL) de acordo com Singh et al. (1995), e analisados em gel de agarose $1,2 \%$ corado com brometo de etídeo.

\section{Seqüenciamento}

Os produtos amplificados via RT-PCR foram seqüenciados pela técnica de reação de terminação em cadeia. Utilizou-se o seqüenciador automático $A B I 377$ e o kit $A B I$ PRISM BigDye Terminator Cycle Sequencing Ready Reaction Kit - Ampli Taq DNA Polymerase, FS (Perkin Elmer) para o sequienciamento automático de fragmentos de DNA ampli- 
Isolado do vírus do mosaico do pepino obtido de bananeira...

Cucumber mosaic virus - RNA 3 ( 2200 nt)

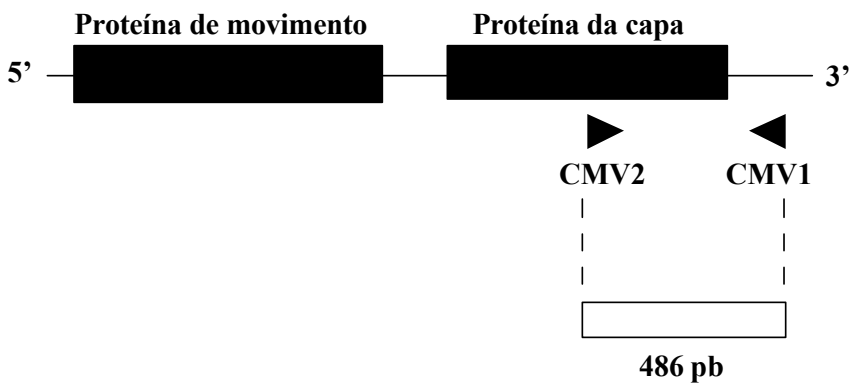

FIG. 1 - Desenho esquemático da estrutura do RNA 3 do Cucumber mosaic virus (CMV). O RNA 3, com cerca de 2200 nucleotídeos (nt.), apresenta 2 ORFs indicadas com barras pretas, que codificam a proteína de movimento e a proteína da capa. As setas representam os oligonucleotídeos utilizados como primers denominados CMV 1 (senso complementar - 2019 ao 2038 nt.) e CMV 2 (senso viral - 1551 ao 1573 nt.). A barra em branco representa o fragmento de DNA, amplificado via RT-PCR, de 486 pares de bases (pb).

ficados via PCR, seguindo as recomendações do fabricante. O seqüenciamento foi realizado nos dois sentidos, ou seja, utilizando-se os dois primers (CMV 1 e CMV 2) e repetido três vezes, a fim de evitar possíveis erros de leitura das bases. $\mathrm{O}$ alinhamento das seqüências obtidas nos dois sentidos (CMV 2 - forward e CMV 1 - reverse) foi feito com o auxílio do programa Sequencer 3.1 (Gene Codes Corporation) e as comparações, com as seqüências existentes no banco de dados GenBank foram feitas através do programa do National Center for Biotechnology Information (NCBI) disponível na internet no endereço http://www.ncbi.nlm.nih.gov/.

\section{RESULTADOS E DISCUSSÃO}

O CMV isolado de bananeira no Estado de São Paulo foi parcialmente caracterizado por Colariccio et al. (1996) e estava armazenado em cloreto de cálcio a -20 ${ }^{\circ} \mathrm{C}$ desde 1994. Após um período de seis anos, este isolado continuou infetivo, o que demonstra a utilidade da técnica, de modo que isolados de vírus possam ser armazenados visando estudos posteriores, sem que haja o risco de diminuição da virulência do isolado ou de alterações devido a mutações.

Os isolados de CMV estão classificados em dois subgrupos (I e II) de acordo com características biológicas, sorológicas e moleculares (Palukaitis et al., 1992). A gama de hospedeiros dos isolados do subgrupo I e II, além de ampla, é semelhante (Carrère et al., 1999). Portanto, para a determinação do subgrupo ao qual pertence o CMV isolado de bananeira foram utilizadas plantas hospedeiras diferenciais e as técnicas de ELISA, RT-PCR, RFLP e seqüenciamento.

$\mathrm{O}$ isolado de CMV foi identificado como pertencente ao subgrupo I através de DAS-ELISA, o qual foi testado simultaneamente contra o AS-CMV I e AS-CMV II. Os valores de absorbância a $405 \mathrm{~nm}$ obtidos para os extratos de $N$. glutinosa infetada foram positivos $(0,70)$ para o anti-soro produzido contra o CMV subgrupo I, e negativos $(0,01)$ para o anti-soro produzido contra o CMV subgrupo II, mostrando que o anti-soro permite uma clara separação entre os dois subgrupos. As plantas sadias não apresentaram reação. $\mathrm{O}$ teste, apesar da sensibilidade, rapidez e baixo custo, pode apresentar problemas para a detecção do CMV direto de extrato de folhas de bananeira infetadas, como constataram $\mathrm{Hu}$ et al. (1995), em que bananeiras com sintomas severos apresentaram resultado negativo em ELISA e positivo em dot blot e RT-PCR. Apesar disso, Colariccio et al. (1996) detectaram o CMV utilizando ELISA e Western blot direto de folhas de bananeira infetada.

Através de RT-PCR, utilizando-se os oligonucleotídeos denominados CMV 1 e CMV 2, desenhados para anelar na porção terminal 3' do RNA 3, foi amplificado um fragmento de DNA com 486 pb (Figura 2, linha 2 e 3). Na amostra de planta sadia não se observou nenhum produto amplificado (Figura 2, linha 8). O produto de PCR (486 pb), submetido à digestão com as endonucleases Eco RI, HindIII, BamHI e Msp I, apresentou um padrão de restrição demonstrando que os produtos da PCR não foram digeridos pelas enzimas EcoRI, HindIII e Bam HI respectivamente (Figura 2. linhas 4, 5 e 6). Porém, quando se utilizou a enzima $M s p \mathrm{I}$, o fragmento de DNA amplificado via RT-PCR (486 pb) foi digerido, originando 2 fragmentos de DNA com 150 e 336 pb (Figura 2, linha 7).

A seqüência de nucleotídeos do fragmento de DNA do CMV amplificado via RT-PCR (Figura 3) foi comparada com outras sequiências depositadas em bancos de dados. As maiores homologias de nucleotídeos encontradas foram de 98\% com o CMV estirpe FNY (U22821), 97\% com as estirpes Y (M57602.1) e C (D00462.1) e 96\% com as estirpes O (D00385.1) e M (D10539.1), todas pertencentes ao subgrupo I. Com as estirpes Q (J02059) e WL (D00463), que pertencem ao subgrupo II, os valores de homologia foram menores, da ordem de $82 \%$. Os valores de homologia de nucleotídeos também foram elevados para os isolados de CMV de bananeira comparados, sendo de $98 \%$ para os isolados de Porto Rico (M98500) e Havaí (U31219), de 97\% para o isolado da Colômbia (U32859) e de $96 \%$ para o isolado da Austrália (Tabela 1). Também foi realizada a comparação de homologia para os aminoácidos deduzidos (Figura 3). Os maiores valores de homologia de aminoácidos foram obtidos para as estirpes FNY, Y, C, O e M, confirmando os resultados obtidos para nucleotídeos (Tabela 2), estando estes resultados de acordo com aqueles obtidos por Singh etal. (1995) e Hu et al. (1995). Através do seqüenciamento, também foi possível determinar o tamanho exato do fragmento amplificado via RT-PCR (486 $\mathrm{pb})$, visto que para os fragmentos amplificados via RT-PCR com os primers CMV 1 e CMV 2, há variação entre 486 e 488 pb para os isolados do subgrupo I e de 499 a 502 pb para os isolados do subgrupo II (Singh et al., 1995). Além disso, o sequienciamento permitiu a identificação do sítio de restrição 


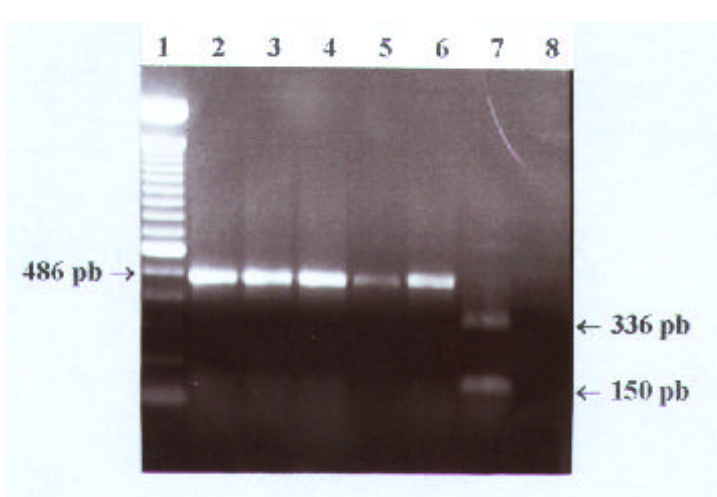

FIG. 2 - Reverse Transcriptase - Polymerase Chain Reaction (RT-PCR) e Restriction Fragment Lenght Polymorphism (RFLP) para o Cucumber mosaic virus (CMV) isolado de bananeira (Musa sp.) no Estado de São Paulo. As linhas 2 e 3 são fragmentos de DNA de 486 pares de bases (pb) amplificados via RT-PCR a partir de RNAs totais extraídos de plantas de Nicotiana glutinosa infetada. As linhas 4, 5 e 6 são fragmentos de 486 pb e representam o resultado da digestão com as enzimas EcoRI, HindIII e BamHI respectivamente. A linha 7 representa o resultado da digestão do fragmento de $\mathbf{4 8 6}$ pb com a enzima MspI, que originaram os fragmentos de 150 e 330 pb. A linha 8 representa a amostra de RNAs totais extraídos de planta sadia. A linha 1 representa o marcador de DNA 100 bp (Gibco BRL).

da enzima $M s p$ I, que corta o DNA amplificado em dois fragmentos de DNA (150 e 330 pb) no nucleotídeo citosina (C), na posição 151(Figura 3).

Quando se compararam as sequiências de aminoácidos dos isolados de CMV do subgrupo I, com a seqüência de aminoácidos deduzidos deste isolado do CMV, verificaramse duas diferenças importantes que correspondem à troca do aminoácido valina (V) por metionina (M) e de alanina (A) por treonina $(\mathrm{T})$ nas posições correspondentes aos nucleotídeos 63 e 283, respectivamente (Figura 3). A troca de alanina por treonina na posição indicada (Figura 3) somente foi observada no isolado Y (Owen et al., 1990), sendo que os demais isolados de CMV, tanto do subgrupo I como do II, inclusive os isolados de bananeira, já seqüenciados, apresentam, nesta posição, o aminoácido alanina. Esta troca representa uma alteração de um aminoácido de cadeias laterais pequenas e apolar para um aminoácido também de cadeias laterais pequenas, porém polar.

A mudança do aminoácido valina para metionina na posição indicada (Figura 3), não foi observada em nenhum outro isolado de CMV (subgrupos I e II) já seqüenciado. Os aminoácidos valina e metionina são ambos compostos por cadeias laterais pequenas e apolares, o que representa uma modificação pequena na estrutura da proteína. Apesar de

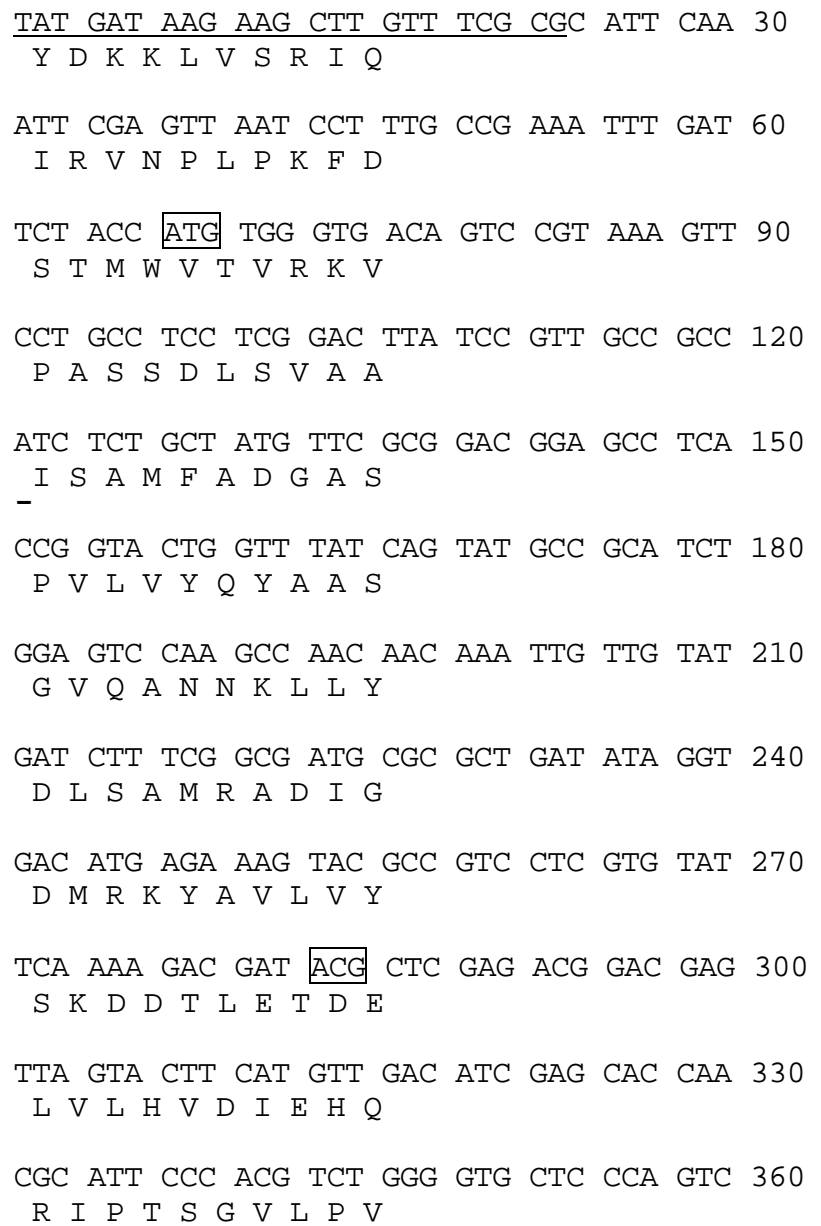

TGA TTCCGCGTTCCCAGAACCCTCCCTCCGATCTCTGTG 399 GCGGGAGCTGAGTTGGCAGTTCTGCTATAAACTGTCTGAA 439 GTCACTAAACGTTTTACGGTGAACGGGTTGTCCATCCAGC 479 TTACGGC 486

FIG. 3 - Seqüência de nucleotídeos (superior) e aminoácidos deduzidos (inferior) do fragmento de DNA do Cucumber mosaic virus (CMV), isolado de bananeira (Musa sp.), amplificado via RT-PCR. Os nucleotídeos sublinhados correspondem aos oligonucleotídeos CMV 1 e CMV 2. Em negrito, está indicado o códon de terminação da proteína da capa proteica. A seta está indicando o sítio de restrição da enzima MspI. As trincas de nucleotídeos indicadas em caixas, correspondem às mudanças dos aminoácidos, quando comparada com outros isolados de CMV. Os nucleotídeos estão numerados a partir da extremidade 5 ' da fita viral.

pequenas, as trocas de aminoácidos, observadas em isolados de CMV, muitas vezes podem resultar em perda da capacidade de transmissão por afídeos, ou também resultar em alterações na expressão dos sintomas apresentados na plantas hospedeiras (Owen et al., 1990). 
TABELA 1 - Comparação (homologia em porcentagem) entre a seqüência de nucleotídeos de 486 pb do Cucumber mosaic virus (CMV) isolado de bananeira (Musa sp.) do Estado de São Paulo com seqüências de outros isolados de CMV depositadas no Genbank*

\begin{tabular}{|c|c|c|c|c|c|c|c|c|c|c|c|c|}
\hline Isolado & $\mathbf{S P}^{1}$ & $\mathbf{P R}^{2}$ & HAV $^{3}$ & $\mathbf{A U S}^{4}$ & FNY $^{5}$ & $\mathrm{COL}^{6}$ & $\mathbf{Y}^{7}$ & $\mathbf{C}^{8}$ & $\mathrm{O}^{9}$ & $\mathbf{M}^{10}$ & $\mathrm{WL}^{11}$ & $\mathbf{Q}^{12}$ \\
\hline $\mathbf{S P}^{1}$ & - & & & & & & & & & & & \\
\hline $\mathbf{P R}^{2}$ & 98 & - & & & & & & & & & & \\
\hline $\mathrm{HAV}^{3}$ & 98 & 97 & - & & & & & & & & & \\
\hline $\mathbf{A U S}^{4}$ & 96 & 97 & 96 & - & & & & & & & & \\
\hline FNY $^{5}$ & 98 & 99 & 99 & 97 & - & & & & & & & \\
\hline $\mathrm{COL}^{6}$ & 97 & 96 & 96 & 97 & 97 & - & & & & & & \\
\hline $\mathbf{Y}^{7}$ & 97 & 96 & 96 & 97 & 95 & 95 & - & & & & & \\
\hline $\mathbf{C}^{8}$ & 97 & 99 & 99 & 96 & 98 & 96 & 96 & - & & & & \\
\hline $\mathbf{O}^{9}$ & 96 & 97 & 97 & 96 & 97 & 94 & 96 & 95 & - & & & \\
\hline $\mathbf{M}^{10}$ & 96 & 97 & 97 & 95 & 97 & 96 & 97 & 97 & 96 & - & & \\
\hline $\mathbf{W L}^{11}$ & 82 & 81 & 80 & 82 & 81 & 81 & 82 & 80 & 80 & 79 & - & \\
\hline$Q^{12}$ & 82 & 81 & 80 & 82 & 80 & 81 & 80 & 80 & 80 & 78 & 94 & - \\
\hline
\end{tabular}

* Utilizou-se o BLAST (n) do NCBI para as comparações entre as sequiências dos diferentes isolados de CMV. 1. Isolado de CMV seqüenciado neste trabalho (SP); 2, 3, 4 e 6 são os isolados de CMV de bananeira de Porto Rico - PR (M98500), do Havaí - HAV (U31219), da Austrália - AUS (Singh et al., 1995) e da Colômbia - COL (U32859) respectivamente. Os números 5, 7, 8, 9 e 10 são isolados de CMV subgrupo I - FNY (U22821), Y (M57602.1), C (D00462.1), O (D00385.1) e M (D10539.1) respectivamente. 11 e 12 são isolados de CMV do subgrupo II - WL (D00463) e Q (J02059) respectivamente. O Código de acesso no banco de dados está indicado entre parênteses ao lado de cada isolado.

Espinha (1999), utilizando RT-PCR seguido de RFLP, comparou um isolado do CMV de Catharantus roseus L. com um isolado do CMV de bananeira proveniente de Minas Gerais e um isolado do CMV de maracujá (Passiflora edulis f. flavicarpa Deg.) proveniente de São Paulo, concluindo que todos os isolados testados pertenciam ao subgrupo I. Estes resultados estão em concordância com a hipótese de prevalência do subgrupo I do CMV em regiões tropicais e subtropicais, conforme observado por Hasse et al. (1989) e no Brasil por Boari et al. (2000) em que ao analisarem 30 isolados do CMV, todos pertenciam ao subgrupo I.

Nos últimos anos, a incidência e a importância do CMV em bananais, tanto no Brasil como nas demais partes do mundo, tem aumentado, sendo registradas perdas na produção de até $80 \%$ (Trindade et al., 1998). Além disso, o transporte e a comercialização de mudas de propagação vegetativa, principalmente de clones provenientes de culturas in vitro vem permitindo a disseminação do vírus, que por apresentar ampla gama de hospedeiras e diversas espécies de afídeos vetores, é facilmente disseminado para novas regiões produtoras.

TABELA 2 - Comparação (homologia em porcentagem) entre a seqüência de aminoácidos deduzidos do Cucumber mosaic virus (CMV) isolado de bananeira (Musa sp.) do Estado de São Paulo com seqüências de outros isolados de CMV depositadas no Genbank*

\begin{tabular}{|c|c|c|c|c|c|c|c|c|c|c|c|c|}
\hline Isolado & $\mathbf{S P}^{1}$ & 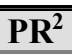 & $\overline{H A V}^{3}$ & $\mathbf{A U S}^{4}$ & FNY $^{5}$ & ${\overline{C \mathrm{COL}^{6}}}^{6}$ & $\mathbf{Y}^{7}$ & $\mathrm{C}^{8}$ & $\mathrm{O}^{9}$ & $\bar{~} \mathbf{M}^{10}$ & 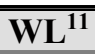 & $\mathrm{Q}^{12}$ \\
\hline SP1 & - & & & & & & & & & & & \\
\hline $\mathbf{P R}^{2}$ & 98 & - & & & & & & & & & & \\
\hline HAV $^{3}$ & 97 & 97 & - & & & & & & & & & \\
\hline $\mathbf{A U S}^{4}$ & 98 & 96 & 95 & - & & & & & & & & \\
\hline FNY $^{5}$ & 98 & 98 & 98 & 97 & - & & & & & & & \\
\hline $\mathrm{COL}^{6}$ & 97 & 97 & 98 & 97 & 98 & - & & & & & & \\
\hline $\mathbf{Y}^{7}$ & 96 & 98 & 95 & 96 & 93 & 98 & - & & & & & \\
\hline $\mathbf{C}^{8}$ & 97 & 98 & 99 & 95 & 95 & 95 & 96 & - & & & & \\
\hline $\mathbf{O}^{9}$ & 96 & 96 & 96 & 95 & 97 & 95 & 95 & 93 & - & & & \\
\hline $\mathbf{M}^{10}$ & 93 & 95 & 96 & 94 & 97 & 95 & 96 & 96 & 94 & - & & \\
\hline $\mathbf{W L}^{11}$ & 82 & 78 & 74 & 80 & 76 & 80 & 79 & 79 & 78 & 77 & - & \\
\hline $\mathbf{Q}^{12}$ & 81 & 80 & 79 & 81 & 81 & 73 & 80 & 80 & 79 & 76 & 95 & - \\
\hline
\end{tabular}

* Utilizou-se o BLAST (p) do NCBI para as comparações entre as seqüências dos diferentes isolados de CMV. 1. Isolado de CMV seqüenciado neste trabalho (SP); 2, 3, 4 e 6 são os isolados de CMV de bananeira de Porto Rico - PR (M98500), do Havaí - HAV (U31219), da Austrália - AUS (Singh et al., 1995) e da Colômbia - COL (U32859) respectivamente. 5, 7, 8, 9 e 10 são isolados de CMV subgrupo I - FNY (U22821), Y (M57602.1), C (D00462.1), O (D00385.1) e M (D10539.1) respectivamente. 11 e 12 são isolados do subgrupo II - WL (D00463) e Q (J02059) respectivamente. O código de acesso no banco de dados está indicado entre parênteses ao lado de cada isolado. 
O isolado do CMV de bananeira, proveniente do Vale do Ribeira, pertence ao subgrupo I A e a inoculação do isolado de CMV em plantas de $V$. unguiculata, resultou na expressão de sintomas de mosaico, que o classifica como pertencente ao subgrupo Ia (Daniels \& Campbell, 1992). Este fato, não descarta a possibilidade da ocorrência de isolados Ib e de isolados do subgrupo II, como já foi observado em bananais na Austrália (Singh et al., 1995).

\section{AGRADECIMENTOS}

Os autores agradecem ao Dr. Marcelo Briones da Universidade Federal de São Paulo por disponibilizar e dar todas as condições necessárias para o seqüenciamento das amostras, à Dra. Elza Maria Frias Martins do Instituto Biológico pelo auxílio na montagem das sequiências e ao senhor Sérgio Vianna do Instituto Biológico de São Paulo, pelo trabalho fotográfico.

\section{REFERÊNCIAS BIBLIOGRÁFICAS}

BOARI, A.J., MACIEL-ZAMBOLIM, E., CARVALHO, M.G \& ZERBINI, F.M. Caracterização biológica e molecular de isolados do "Cucumber mosaic virus" provenientes de oito espécies vegetais. Fitopatologia Brasileira 25:4958. 2000.

CARRÈRE, I., TEPFER, M. \& JACQUEMOND, M. Recombinants of cucumber mosaic virus (CMV): determinants of host range and symptomatology. Archives of Virology 144:365-379. 1999.

CHOI, S.K., CHOI, J.K., PARK, W.M. \& RYU, K.H. RTPCR detection and identification of three species of cucumoviruses with a genus-specific pair of primers. Journal Virological Methods 83:67-73. 1999.

CHOMCZYNSKI, P. \& SACCHI, N. Single-step method of RNA isolation by acid guanidinium thiocyanate-phenolchloroform extraction. Analytical Biochemistry 162:156159. 1987.

COLARICCIO, A., EIRAS, M., VICENTE, M., CHAGAS, C.M. \& HARAKAVA, R. Caracterização parcial de um isolado do vírus do mosaico do pepino de Musa sp. "nanicão". Fitopatologia Brasileira 21:268-274. 1996.

CONVERSE, R.H. \& MARTIN, R.R. Elisa methods for plant viruses. In: HAMPTON, R., BALL, E.M. \& DE BOER, S. (Eds.). Serological methods for detection and identification of viral and bacterial plant pathogens. St. Paul, APS Press. 1990. pp. 179-196.

DANIELS, J. \& CAMPBELL, R.N. Characterization of Cucumber mosaic virus isolates from California. Plant Disease 76:1245-1250. 1992.

EDWARDS, M.C. \& GONSALVES, D. Grouping of seven biologically defined isolates of cucumber mosaic virus by peptide mapping. Phytopathology 73:1117-1120. 1983.

EIRAS, M., RESENDE, R.O. \& DE ÁVILA, A.C. Detecção de vírus de plantas através de Reação em Cadeia da Polimerase. Fitopatologia Brasileira 23:5-17. 1998.
ESPINHA, L.M. Caracterização de um isolado do vírus do mosaico do pepino obtido de Catharantus roseus. (Dissertação de Mestrado). São José do Rio Preto. Universidade Estadual Paulista. 1999.

HASSE, A., RICHTER, J. \& RABEINSTEIN, F. Monoclonal antibodies for detection and sero-typing of cucumber mosaic virus. Journal of Phytopathology 127:129-136. 1989.

HSU, H.T., BARZUNA, L., HSU, Y.H., BLISS, W. \& PERRY, K.L. Identification and subgrouping of CMV with mouse monoclonal antibodies. Phytopathology 90:615-620. 2000.

HU, J.S., LI, H.P., BARRY, K., WANG, M. \& JORDAN, R. Comparison of dot blot, ELISA and RT-PCR assays for detection of two cucumber mosaic virus isolates infecting banana in Hawaii. Plant Disease 79:902-906. 1995.

LIMA, J.A.A. \& GONÇALVES, M.F. Identificação sorológica do vírus do mosaico do pepino em plantações de bananeira do Ceará. Fitopatologia Brasileira 13:26. 1988 (Resumo).

MACIEL-ZAMBOLIM, E., ZERBINI, F.M., CARVALHO, M.G. \& GILBERTSON, R.L. Identification of CMV subgroup I and II isolates based on biological and molecular properties. Fitopatologia Brasileira 22:344. 1997 (Resumo).

MAGEE, C.P. A new virus disease of banana. Agric. Gaz. New South Wales 41:929. 1930.

MEDEIROS, A.G. Nota sobre a ocorrência de mosaico em bananeira no Estado de Pernambuco. Boletim Técnico Instituto de Pesquisa Agropecuária (Recife) 4:1-13. 1963.

OWEN, J., SHINTAKU, M., AESCHLEMAN, P., TAHAR, S.B. \& PALUKAITIS, P. Nucleotide sequence and evolutionary relationships of cucumber mosaic virus (CMV) strains: CMV RNA 3. Journal of General Virology 71:2243-2249. 1990.

PALUKAITIS, P., ROOSINCK, M.J., DIETZGEN, R.G. \& FRANCKI, R.I.B. Cucumber mosaic virus. Advances in Virus Research 41:281-341. 1992.

RIBEIRO, M.I.S.D., RIBEIRO, R.L.D., MAIOLINO, W. \& ROBBS, C.F. Nota sobre a ocorrência de uma forma severa de mosaico em bananais do Estado do Rio de Janeiro. Revista da Sociedade Brasileira de Fitopatologia 6, 7, 8:26-28. 1975.

RIZOS, H., GUNN, L.V., PARES, R.D. \& GILLINGS, M.R. Differentiation of cucumber mosaic virus isolates using the polymerase chain reaction. Journal of General Virology 73:2099-2103. 1992.

SINGH, Z., JONES, R.A.C. \& JONES, M.G.K. Identification of cucumber mosaic virus subgroup I isolates from banana plants affected by infectious chlorosis disease using RT-PCR. Plant Disease 79:713-716. 1995.

TRINDADE, D.R., POLTRONIERI, L.S., ALBUQUERQUE, F.C., BENCHIMOL, R.L. \& AMORIM, A.M. Ocorrência do CMV em bananeira no Estado do Pará. Fitopatologia Brasileira 23:185. 1998.

VAN REGENMORTEL, M.H.V., FAUQUET, C.M., BISHOP, 
Isolado do vírus do mosaico do pepino obtido de bananeira...

D.H.L., CARSTENS, E.B., ESTES, M.K., LEMON, S.M., MANILOFF, J., MAYO, M.A., McGEOCH, D.J., PRINGLE, C.R., WICKNER, R.B. Virus Taxonomy Classification and Nomenclature of Viruses. Seventh Report of the International Committee on Taxonomy of Viruses.
Academic Press, California, USA, 2000.

WYLIE, S., WILSON, C.R., JONES, R.A.C. \& JONES, M.G.K. A polymerase chain reaction assay for cucumber mosaic virus in lupin seeds. Australian Journal Agricultural Research 44:41-51. 1993. 